Open Access

Research Article
Res. Agric. Livest. Fish. Vol. 2, No. 3, December 2015: 475-482

\title{
HAEMATHOLOGICAL AND HISTOLOGICAL EVALUATION OF AFRICAN CATFISH Clarias gariepinus FOLLOWING ACUTE EXPOSURE TO METHANOLIC EXTRACT OF Khaya senegalensis
}

\section{Matouke Matouke Moise ${ }^{1^{*}}$ and Obadiah Audu Abui ${ }^{2}$}

'Department of Biological Sciences, Federal University, Dutsinma, Katsina, Nigeria; 2Department of Biological Sciences, Federal Science and Technical College, Kafanchan, Kaduna State, Nigeria

*Corresponding author: Matouke Matouke Moise, E-mail: mosesmatouke@yahoo.fr

\begin{tabular}{|c|c|}
\hline ARTICLE INFO & ABSTRACT \\
\hline $\begin{array}{l}\text { Received } \\
12.10 .2015 \\
\text { Accepted } \\
07.12 .2015 \\
\text { Online } \\
21.12 .2015 \\
\text { Key words } \\
\text { Haematology } \\
\text { Histopathology } \\
\text { Clarias gariepinus } \\
\text { Methanol extract }\end{array}$ & $\begin{array}{l}\text { Haematological and histopatholoical effects of methanolic extract of } K \text {. senegalensis } \\
\text { leaves was investigated on Clarias gariepinus over a period of } 96 \mathrm{~h} \text { exposure. The } \\
\text { median lethal concentration of the extract was } 199.69 \mathrm{mg} / \mathrm{L} \text {. The extract caused } \\
\text { decreased in total erythrocytes (TEC) and Packed Cell volume (PCV) respectively and } \\
\text { increased of total leukocytes (TLC). Histopathological lesions in the liver, cytoplasmic } \\
\text { degeneration, less intracellular space, mild necrosis, sinusoidal blood congestion and } \\
\text { marked blood congestion in hepathocytes were recorded. However the severity but not } \\
\text { the type of lesions was concentration-dependent. Though, the degree of tissue change } \\
\text { (DTC) varied with the methonolic extract used. There was significant association } \\
\text { (P<0.05) between the DTC and } K \text {. senegalensis methanolic concentration. The } \\
\text { cumulative DTC indicated a moderate damage in the liver. The extract was considered } \\
\text { toxic to the exposed fish and therefore deleterious on the organs of } C \text {. gariepinus. }\end{array}$ \\
\hline
\end{tabular}

To cite this article: Matouke MM and OA Abui, 2015. Haemathological and histological evaluation of African catfish Clarias gariepinus following acute exposure to methanolic extract of Khaya senegalensis. Res. Agric. Livest. Fish. 2 (3): 475-482.

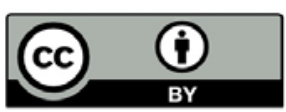

This is an open access article licensed under the terms of the Creative Commons Attribution 4.0 International License

www.agroaid-bd.org/ralf, E-mail: editor.ralf@gmail.com 


\section{INTRODUCTION}

Khaya senegalensis is commonly used in Africa for shade, medicinal purposes and belong to the Meliacea family (Adanhounsode, 2012). Due to anthropogenic activities the plant stem and leaves might be found in the aquatic ecosystem which could be a serious threat for aquatic fauna including Clarias gariepinus. Exposure of aquatic organism to plant extract has been shown to have detrimental effects on fish physiology sometimes leading to mortality (Abalaka, 2015).Fish species are permanently exposed to their ecosystem and thus, exposure to a peculiar compound can act as environmental indicator. Hematology and histhopathology have been used as a biomarker for the effects of various anthropogenic pollutants on fish (Olurin et al., 2006; Devi and Mishra, 2013).

Studies showed the impact of haematology and gill pathology of Heterobranchus bidorsalis exposed to sub lethal concentration of Moringa oleifera leaf extract. Erythrocytes was $2.36 \times 106 / \mathrm{mm}^{3}$, Packed Cell Volume was $20 \%$, Haemoglobin was $6.68 \mathrm{~g} / \mathrm{dl}$, mean cell volume was $85.1 \mathrm{ft}$, cell haemoglobin concentration was 33.33 and mean cell concentration was $28.8 \mathrm{pg}$ while the mean value for white blood cell was $40.5 \mathrm{~mm}^{3}$. These results suggest a variation of values when compared to control (Olufayo and Olufunke, 2012). Many other studies showed similar variation of haematological parameters (Mammanet al., 2013; Ochang, 2007; Odeyemoet al., 2010).However, Oreochromis niloticus showed hispathological responses while exposed to waterborne copper, the gills were affected with edema, lifting of lamellar epithelia and an intense vasodilatation of the lamellar vascular axis. In the liver, the number of hepatocytes nucleus per $\mathrm{mm}^{2}$ of hepatic tissue decreased with the increase of copper concentration (Figueiredo-Fernandes, 2007). In india, metal uptake by Oreochromis mossambicus inhabiting Indus River led to histological changes in gills and liver. The abnormalities in gills were desquamation of lamellar epithelium, hypertrophy of epithelial cells, lifting up lamellar epithelium, intraepithelial oedema, aneurysm, hyperplasis and haemorrhage. Histology of liver revealed the presence of heterogenous parenchyma characterized by vacuolization, foci of necrosis, hypertrophy of nuclei and degenerated hepatocytes (Jabeen and Chaudhry, 2013).

Intensive research on the environmental impact of chemical compound in aquatic ecosystem and also the effects of some stem bark and leaves of some plant with prominent medicinal purposes including $K$. senegalensis have been documented. However, a dearth of information about the methanolic extract of the leaves on aquatic fauna including $C$. gariepinus still exists. The study therefore aimed to evaluate the haematological indices and histopathological changes in the liver of Clarias gariepinus exposed to acute concentration of Khaya senegalensis.

\section{MATERIALS AND METHODS}

\section{Plant extraction}

$K$. senegalensis leaves were dried in an open airy laboratory for 2 weeks and later and pounded into powder using ceramic mortar and pestle and later sieved through $100 \mathrm{~mm}$ sieve to obtain $500 \mathrm{~g}$ of fine powder. $200 \mathrm{~g}$ of the powder was packed into a soxhlet extractor with $5 \mathrm{~L}$ of $25 \% \mathrm{v} / \mathrm{v}$ methanol $(98 \%$ vol. SigmaAldrich $^{R}$ Inc., St. Louis, MO 63178, USA) as the extracting solvent. The set up was placed over water bathbath $\left(40-45^{\circ} \mathrm{C}\right)$ for 3 to $4 \mathrm{~h}$ for drying the substrate.

\section{Acute fish toxicity bioassay}

Three (300) Juveniles $C$. gariepinus of mean weight $18.47 \pm 3.06 \mathrm{~g}$ and standard length $10.9 \pm 2.7 \mathrm{~cm}$. Fish were acclimatized in 500L plastic tank pond for 14 days under natural day and night photoperiods $(12 / 12 \mathrm{~h})$ prior to commencement of the toxicity bioassay. Pond water was changed once every three (3) days. Fish were fed twice daily with standard feed for aquaculture.

Three hundred and sixty (360) healthy acclimatized fishes were randomly selected and distributed into 12 glass aquaria each containing 20 litres of dechlorinated water of 10 fish per aquaria, two of the aquaria served as control for acute toxicity bioassay. Twenty gram of the methanolic extract of $K$. senegalensis was obtained and dissolved in distilled water (1L) to form a stock solution of 250mg/L. 0 (control), 150, 170, 190, 210 and $230 \mathrm{mg} / \mathrm{L}$ were dispersed into the experimental aquaria. The mixture was allowed to stand for about five minutes to evenly distribute via diffusion before introducing the fish. The exposure was carried out in triplicate. 
At the end of the $96 \mathrm{~h}$ exposure period, two fish were randomly sampled from the control and each treatment tanks, dissected to extract the liver.

The concentrations were selected after conducting a preliminary study, was used as an endpoint of toxicity. Probit analysis method was used to determine the median lethal concentration ( $\mathrm{LC}_{50}$ of the extract of the exposed fish. The temperature, PH, TDS, Conductivity of fish culture water was ascertained using a Hana portable hand instrument $\mathrm{HI} 98129$ and the dissolved oxygen contents were measured using Winkler-Azide method and reported elsewhere (Abui and Matouke, 2015).

\section{Haematological analyses}

Total Erythrocytes (TEC) and total leucocytes (TLC) count were evaluated using an improve Neubaeur counting chamber under microscope (Dacei and Lewis, 2001). PCV was evaluated by Wintrobe method (Blaxhall and Diasley, 1971).

\section{Histopathological analyses}

At the end of the $96 \mathrm{~h}$ exposure period, two fish were randomly sampled from the control and each treatment tanks, dissected to extract the tissues (liver). The liver was preserved in $10 \%$ formalin, washed in running tap water to remove traces of formalin, followed by dehydration using progressive percentage of alcohol and chloroform. Samples were processed, sectioned $(5 \mu \mathrm{m})$ and stained with haematoxylin and eosin using histological techniques (Bancroft and Cook 1994). Permanent slides were prepared and photomicrographs taken, using a Carl Zeiss (Axioskope 40) Trinocular Photo micrographic microscope with digital camera for comparison with tissues obtained from those of control.

The degree of tissue change (DTC), which is based on the severity of the lesions according to the methodology described by Poleksic and Mitrovic-Tutundzik (1994). For the calculation of DTC, the alteration in the liver was classified in progressive stages of tissue damage. First stage lesions (I) are slight and would be reversible with an improvement in the environmental conditions; second-stage lesions (II) are more severe, leading to effects on tissue function; and third-stage lesions (III) are very severe, with irreparable damage. The sum of the number of lesion types within each of the three stages multiplied by the stage coefficient represents the numerical value of the DTC, based on the formula DTC $=\left(10^{0} \Sigma \mathrm{I}\right)+\left(10^{1} \Sigma \mathrm{II}\right)+\left(10^{2} \Sigma \mathrm{III}\right)$, in which I, II and III correspond to the sum of the number of alterations found in stages I, II and III, respectively. The DTC was obtained for the fish of all the experimental groups and used in the statistical analysis to compare the mean degree of tissue damage between groups.

\section{Statistical analyses}

Data were analyzed using XLSTAT software version 15.5. Means (SD) were subjected to ANOVA and Chi-square for statistical significance $(P<0.05)$.

\section{RESULTS}

\section{Quality of the water}

The physicochemical parameters of water showed that EC was $79.5 \mu \mathrm{s} / \mathrm{cm}$, TDS $56.79 \mathrm{mg} / \mathrm{L}, \mathrm{PH} 6.92$ and Temperature $24.14{ }^{\circ} \mathrm{C}$ (Table 1$)$.

Table 1. Physicochemical parameters of fish culture water of C. gariepinus exposed to methanol extract of leaves $K$. senegalensis.

\begin{tabular}{|ll|}
\hline Physicochemical parameters & Value \\
\hline Conductivity $(5 \mu \mathrm{s} / \mathrm{cm})$ & $79.5 \pm 3.48$ \\
Total dissolved solid $(\mathrm{TDS}) \mathrm{mg} / \mathrm{L}$ & $56.79 \pm 1.81$ \\
$\mathrm{PH}$ & $6.92 \pm 0.12$ \\
Dissolved oxygen $(\mathrm{DO})\left(\mathrm{mgO}_{2} / \mathrm{L}\right)$ & $6.66 \pm 0.14$ \\
Temperature $\left({ }^{\circ} \mathrm{C}\right)$ & $24.14 \pm 0.18$ \\
\hline
\end{tabular}




\section{Acute fish toxicity bioassay}

The effect of $K$. senegalensis leaves on C. gariepinus showed a high mortality of 60,83 and 70 at concentration 210 and $230 \mathrm{mg} / \mathrm{l}$ respectively. The mortality increased significantly with the increased in concentration $(P<0.05)$. The median lethal concentration (LC50) of leaves extract was therefore $199.69 \mathrm{mg} / \mathrm{L}$ (Table 2).

Table 2. Mortality in C. garipinus exposed to methanol extract of $K$. senegalensis leaves over $96 \mathrm{~h}$ period.

\begin{tabular}{|lllll|}
\hline $\begin{array}{l}\text { Extract concentration } \\
\text { (mg.L) }\end{array}$ & $\begin{array}{l}\text { Log } \\
\text { concentration }\end{array}$ & $\begin{array}{l}\text { Total } \\
\text { Mortality }\end{array}$ & $\begin{array}{l}\text { Percentage total } \\
\text { mortality (\%) }\end{array}$ & Probit value \\
\hline 0.0 (control) & 0.000 & 0.0 & $0.0^{*}$ & $2.5^{*}$ \\
$150 \mathrm{mg} . \mathrm{L}$ & 2.176 & 1 & 10 & 3.72 \\
$170 \mathrm{mg} . \mathrm{L}$ & 2.230 & 3 & 30 & 4.16 \\
$190 \mathrm{mg} . \mathrm{L}$ & 2.279 & 4 & 40 & 4.75 \\
$210 \mathrm{mg} \cdot \mathrm{L}$ & 2.322 & 6 & 60 & 5.25 \\
$230 \mathrm{mg} \cdot \mathrm{L}$ & 2.362 & 7 & 70 & 5.52 \\
\hline
\end{tabular}

$\mathrm{Y}=9.33 \mathrm{x}-21.47, \mathrm{LC}_{50}=199.69,{ }^{*}=$ corrected value

The surface of $C$. gariepinus liver in control group had a preserved architecture, normal hepatocytes and absence of blood congestion while compared to other concentration (Figure 1, 2, 3, 4, 5, 6 and 7).
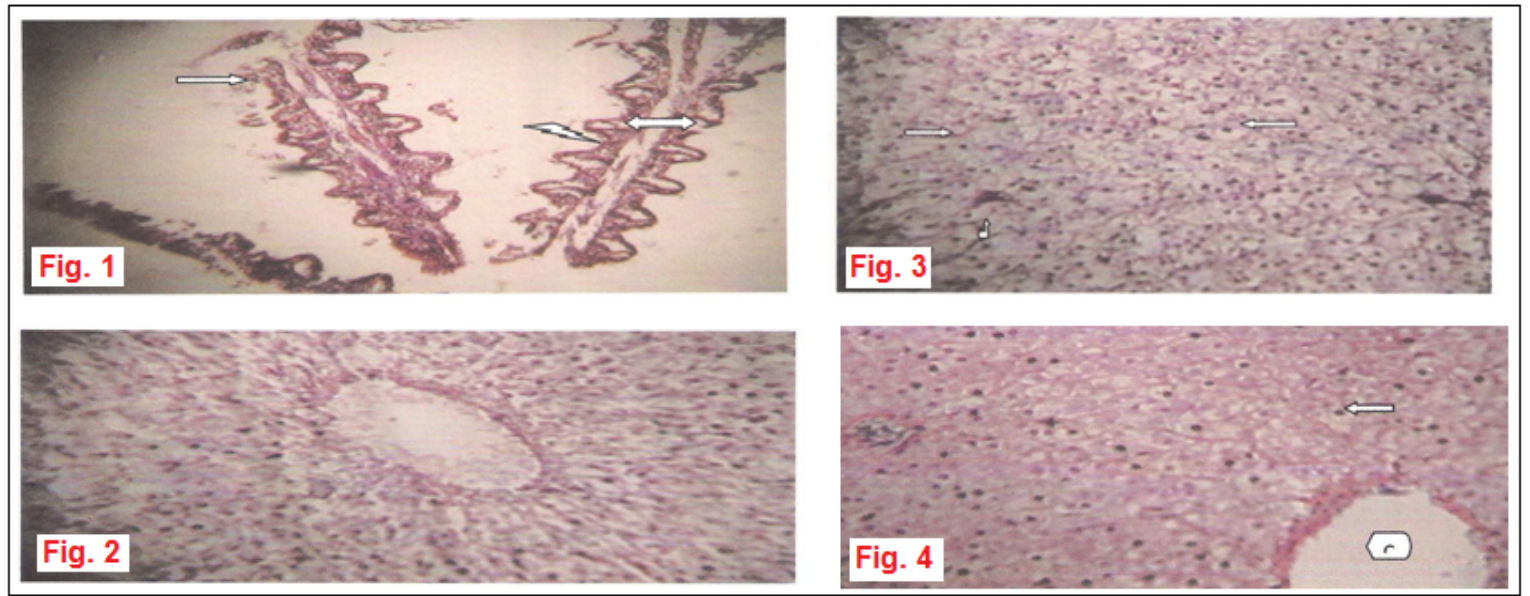

Figure 1. Photomicrograph of the liver of $C$. gariepinus showing a preserved architecture and normal hepatocytes with sinusoids intact; Figure 2. Photomicrograph of the liver of $C$. gariepinus showing a preserved architecture and necrosis of the hepatocytes at $170 \mathrm{mg} / \mathrm{L}$ of toxicant; Figure 3. Photomicrograph of the liver of $C$. gariepinus showing mild necrosis of the hepatocytes at $190 \mathrm{mg} / \mathrm{L}$ of toxicant; and Figure 4. Photomicrograph of liver of C. gariepinus showing marked necrosis of the hepatocytes at $210 \mathrm{mg} / \mathrm{L}$ of toxicant.

\section{Haematological evaluation}

The haematological evaluation showed the highest means total erythrocyte concentration (TEC) (238 \pm 3.0$)$ at concentration $150 \mathrm{mg} / \mathrm{L}$ and the lowest $(122.33 \pm 4.16)$ at concentration $230 \mathrm{mg} / \mathrm{L}$. The total leucocytes concentration in the blood sample was highest $(2888 \pm 16)$ and the lowest 1147.23 at control level. The pack cell volume (PCV) was the highest (39.13) during control and the lowest $13.67 \pm 1.53$ at concentration $230 \mathrm{mg} / \mathrm{L}$ (Table 3). There was no significant difference among means of haematological parameters. 
Table 3. Means of haematological parameters on Clarias gariepinus to acute concentration of methanol leaf extract of Khaya senegalensis.

\begin{tabular}{|llll|}
\hline Concentration $\mathbf{~ m g / L}$ & TECx10 & TLCX500 $\mathbf{~ m}^{\mathbf{3}}$ & PCV \\
\hline 0 & $252^{\mathrm{a}}$ & $1147.23^{\mathrm{c}}$ & $39.13^{\mathrm{a}}$ \\
150 & $238 \pm 3.0^{\mathrm{b}}$ & $1626.67 \pm 16.65^{\mathrm{d}}$ & $31 \pm 2.0^{\mathrm{a}}$ \\
170 & $212.0 \pm 2.65^{\mathrm{c}}$ & $2072 \pm 8.0^{\mathrm{c}}$ & $23.67 \pm 2.51^{\mathrm{b}}$ \\
190 & $201 \pm 3.0^{\mathrm{d}}$ & $2422.67 \pm 28.4^{\mathrm{b}}$ & $21.33 \pm 3.06^{\mathrm{b}}$ \\
210 & $159.33 \pm 1.53^{\mathrm{e}}$ & $2870.67 \pm 22.03^{\mathrm{a}}$ & $13.33 \pm 3.06^{\mathrm{c}}$ \\
230 & $122.33 \pm 4.16^{\mathrm{f}}$ & $2888 . \pm 16^{\mathrm{a}}$ & $13.67 \pm 1.53^{\mathrm{c}}$ \\
\hline
\end{tabular}

Means with the same letters along the columns are not significantly different $(P>0.05)$.

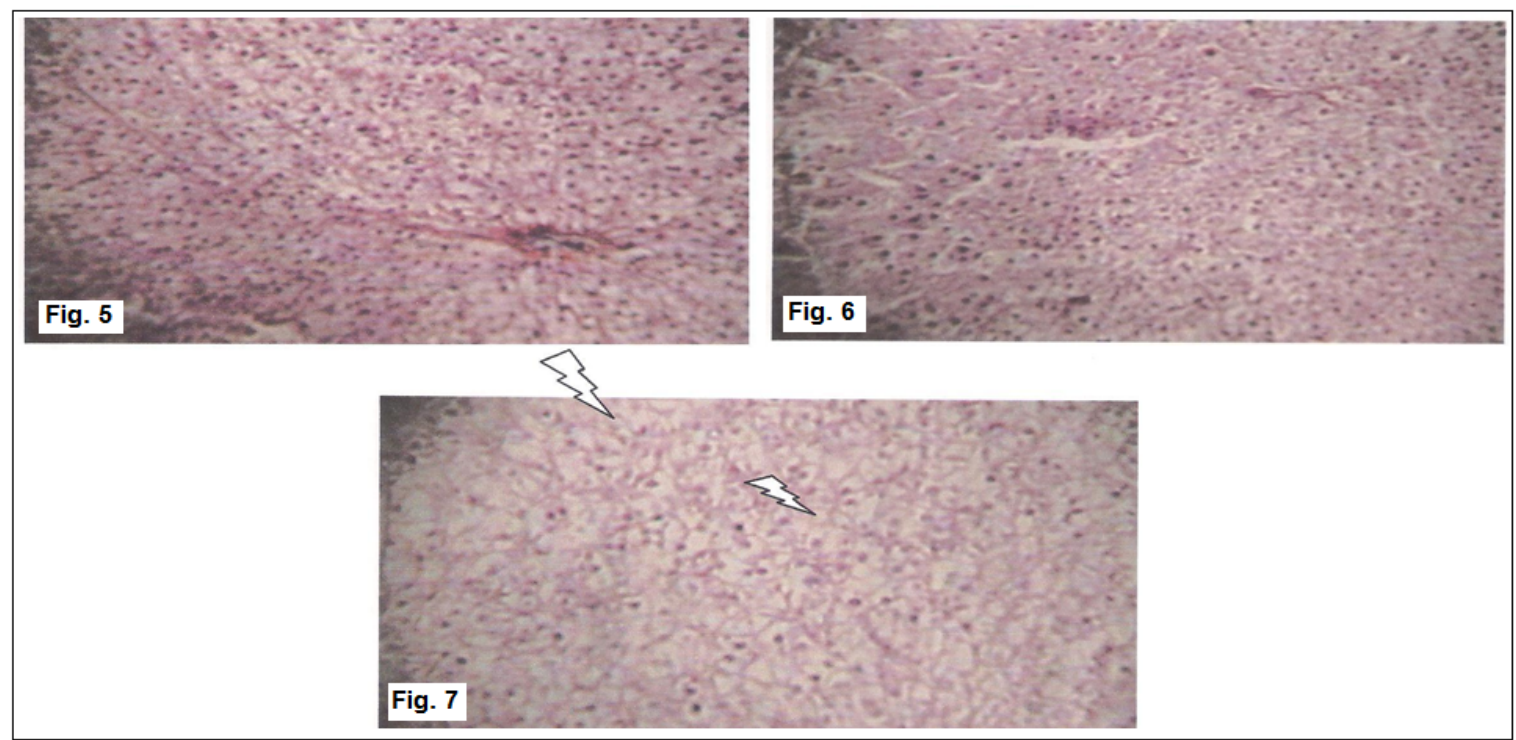

Figure 5. Photomicrograph of the liver of C. gariepinus showing marked necrosis of hepatocytes at $230 \mathrm{mg} / \mathrm{L}$ of toxicant; Figure 6. Photomicrograph of the liver of $C$. gariepinus showing marked necrosis of hepathocytes at 230 $\mathrm{mg} / \mathrm{L}$ of toxicant; and Figure 7. Photomiccrograph of the liver of C. ganepius showing marked necrosis of hepatocytes at $230 \mathrm{mg} / \mathrm{L}$ of toxicant.

Table 4. Type and incidence of histological lesion in the liver of Clarias gariepinus exposed to methanol extract of Khayasenegalensis leaves over $96 \mathrm{~h}$ periods.

\begin{tabular}{|ll|}
\hline Stage & Degree of tissue damage in the Liver \\
\hline I & Degeneration of the cytoplasm(++) \\
& Less intracellular space $(++)$ \\
II & Mild necrosis $(++)$ \\
& Sinusoidal blood congestion $(+++)$ \\
III & Marked blood congestion in hepathocyte $(++)$ \\
\hline
\end{tabular}

$(+)$ : low incidence $(++)$ : moderate incidence $\quad(+++)$ : high incidence 
The degree of tissue change (DTC) was highest (111.67) when the fish was exposed to $230 \mathrm{mg} / \mathrm{L}$ concentration, this translate irreversible damage observed. The DTC of 72 which is moderate was observed when the fish was exposed to $210 \mathrm{mg} / \mathrm{L}$ while the concentration less than $210 \mathrm{mg} / \mathrm{L}$ was without danger for the liver of the fish (Table 5). The result showed significant difference when compared to the control $(P<0.05)$. The cumulative degree of tissue change showed a moderate change $(55.06 \pm 12.7)$ in the liver of fish (Table 6).

Table 5. Degree of tissue change per extract concentration in the liver of Clarias gariepinus exposed to methanol extract of Khaya senegalensis leaves over $96 \mathrm{~h}$ period.

\begin{tabular}{|lllllll|}
\hline Concentration & $\mathbf{0 0}$ & $\mathbf{1 5 0}$ & $\mathbf{1 7 0}$ & $\mathbf{1 9 0}$ & $\mathbf{2 1 0}$ & $\mathbf{2 3 0}$ \\
\hline Liver & $12 \pm 8.5$ & $53 \pm 9$ & $42.67 \pm 30.2$ & $39 \pm 11$ & $72 \pm 11$ & $111.67 \pm 6.6$ \\
\hline
\end{tabular}

\section{DISCUSSION}

The physical and chemical parameters analyzed in this study are very relevant for the status of water quality tolerable by C. gariepinus. The result of the physical chemical in this study, conductivity $79.5 \mu \mathrm{s} . \mathrm{cm}$, TDS $56.79 \mathrm{mg} / \mathrm{L}$, Temperature $24.14^{\circ} \mathrm{C} \mathrm{PH} 6.92$ and DO $6.66 \mathrm{mgO}_{2} 132 \mathrm{mg} / \mathrm{L}$ corroborate with the standard of freshwater fish water quality. The physicochemical parameters of fish culture water in this study were all within acceptable limit for the survival of $C$. gariepinus. The standard as stated by Kalawole et al. (2011) reported a conductivity less than $135-100 \mu \mathrm{s} / \mathrm{cm}$, DO greater than $4 \mathrm{mg} / \mathrm{L} ; \mathrm{PH}$ between 6.5 to 9 and Temperature between $20-30{ }^{\circ} \mathrm{C}$.

In this study the mortality increased with the increase of concentration, this increase was shown to be significant $(P<0.05)$. This showed that methanolic extract of $K$. senegalensis was 138 toxic to the exposed fish. The dependence of plants extract to mortality of C. gariepinus was similar Abalaka et al. (2015). The LC 50 value of 199.69 in this study was higher compared to Ayuba et al. (2012) who had a LC50 of $120.23 \mathrm{mg} / \mathrm{L}$ while studying the acute toxicity C. gariepinus exposed to Daturainnoxia leaf extract.

A decrease of total erythrocytes observed in this study when compared to the control suggests a gradual damage or inhibition of oxygen production of erythrocytes in the blood of fish. The increased and decreased values of TLC suggest some abnormalities. Leukocytes are white colored blood cells which defend the animal body against infections and diseases. They might increase in number in this study to boost the immunity of fish against certain infections due to variation of concentration extract. The PCV measures the percentage of red blood cells $(\mathrm{RBC})$ to the total blood volume. These values obtained in this study decreased respectively with the increase of concentration which suggests an increase of anemia in fish. This study agreed with finding on the haematological responses of Clarias gariepinus exposed to sublethal concentration of Daturainnoxia root extract (Okomodaetal, 2013). K. senegalesis could be suspected to cause gradual anemia in fish through hemolysis though no significant difference was observed in the measured haematological parameters.

Using the methods described by Polekesic and Mitrovic-Tutundsie (1994) as reference, five (5) types of lesions were identified in the liver of $C$. gariepinus (Table 4). Two (2) of which were first stage (I), two (2) were second stage (II) and one (1) was stage three (III).

The liver is the organ most associated with detoxification and accumulation due to the function and blood supply, it is also affected by contaminant in the ecosystem and also play a critical role in fish physiology because acts as the main storage for many substance (Moneim-Abdel et al., 2008). Histopathological changes of liver in this study gave an insight on the nature of the stressor $K$. senegalensis leading to pathological changes in tissues. In this study the damage in the liver of $C$. gariepinus exposed to various concentration accounts for the response to the methanol extract $K$. senegalensis which act as a toxicant. The response in the liver tissues showed a degeneration of the cytoplasm, less intracellular, mild necrosis, sinusoidal blood congestion and marked blood congestion in hepathocytes. These changes may be attributed to direct toxic effects of pollutants on hepatocytes as found in $K$. senegalensis. The observation in this study suggests a structural damage of the hepatocytic cytoplasm with gradual increase of $K$. senegalensis concentration. Elsewhere, authors described hepathocytic alterations, hypertrophy of hepatocytes, and infiltration of leukocytes, necrosis and fibrosis in Channapunctatus a freshwater fish after exposure to pesticide chlorpyrifos (Devi and Mishra, 2013). 
Less intracellular spaces, mild necrosis, sinusoidal congestion and marked blood congestion in this study might be the cause of the degeneration of hepathocytes with cytoplasmic vacualation and hypertrophy. These observations were reported in Poeciliareticulate exposed to acute concentration of textile effluent (Selvaraj et al., 2015). Increased vacualisation of the hepathocytes could be described as a signal of degenerative process. Cytoplasmic degeneration in this study suggests metabolic damage, probably related to exposure to acute $K$. senegalensis.

Marked blood congestion and marked necrosis lesions belonging to stage I and stage II respectively observed in this study were in agreement with many studies that examined the effect of different pollutant on fish liver, though the pollutant were metals (Olurin et al., 2006, Figueiredo-Fernandes et al., 2007; Devi and Mishra, 2013; Jabeen and Chaudhry, 2013).

The highest mean DTC was observed at concentration $230 \mathrm{mg} / \mathrm{L}$ might suggest a severe damage in the hepatic cells if prolonged. But the cumulative mean of 55.06 was observed in the liver of fish exposed to acute concentration. This result agreed with findings of (Carmago and Martinez, 2007) which report showed a mean DTC of 52.34 indicating that in most cases the hepatic lesions caused moderate damage to tissues though, an increase of DTC 174 in summer was reported while studying the histopathology of liver of a Neotropical fish caged in an urban stream. Studies conducted on the gills and skin of C. gariepinus exposed to acute concentration of ethanol extract of Adenium obesumstem bark revealed a cumulative DTC of 23.12 and 1.78 in the gills and skin respectively which suggest a low damage while compared to the present study.

\section{CONCLUSION}

In the present study, haematological parameters (TEC TLC and PCV) and histopatological changes have been related to acute concentration of $K$. senegalensis. It can be concluded that haematological indices and liver alteration of fish may serve as biomarker of toxicity due to acute concentration of $K$. senegalensis. However, other studies are necessary to evaluate de degree of tissue change in other species of fish.

\section{CONFLICT OF INTEREST}

The authors have no conflicts of interest concerning the work reported in this paper.

\section{REFERENCES}

1. Abalaka SE, Muhammad, YF, Najume, DG and SF Ambali, 2015. Gills and skin histopatholigicalevaluation in African Shaptooth catfish, Clarias gariepinus exposed to ethanol extract of Adenium obesum stem bark. Egyptian Journal of Aquatic Research, 41: 119-127.

2. Abui OA and MM Matouke, 2015. Toxicological evaluation of methanol extract of Khaya senegalensis leaves in African catfish Clarias gariepinus. Journal of Applied Science and Environmental Management, 19: 557-560.

3. Adanhounsode SN, 2012. Problematique de l'utilisation de khayas enegalensis comme arbre de reboisement urbain cas de la ville de cotonou. These publiee pour l'obtention du diplome de licence professionnelle. Ecole Polytechnique d'Abomey Calavi. www.memoireen ligne.com.

4. Ayuba VO, Ofojekwu PC and SO Musa, 2012. Haematological response and weight changes of the African Catfish Clarias gariepinus exposed to Sub-lethal concentration of Daturainnoxia root extract. Production and Agriculture Technology, 8: 134-143.

5. Bancroft JD and HC Cook, 1994. Manual of Histological Techniques and their Diagnostic Application. Churchill Livingstone, London, pp. 289-305.

6. Blaxhall PC and Diasley KW, 1973. Routine haematological methods for use with fish blood. Journal of Biology, 5: 771-781.

7. Carmago MM and C Martinez, 2007. Histopathology of gills, kidney and liver of a Neotropical fish caged in an urban stram. Neotropical Ichthyology, 5: 327-336.

8. Dacei JW and SM Lewis, 2001. Practical haematology, $9^{\text {th }}$ ed Churchill, Livingston, London. 
9. Figueiredo-Fernandes A, Ferreira-Cardoso JV and S Garcia-Santos, 2007. Histopathological changes in liver and gill epithelium of Nile tilapia, Oreochromis niloticus, exposed to water borne copper. Prequisa. Veterina. Brasileira, 27: 103-109.

10. Jabeen Farbeen A and AS Chauhry, 2013. Metal uptake and histological changes in gills and liver of Oreochromis mossambicua inhabiting Indus River. Paskitan Journal of Zoology, 45: 9-18.

11. Kalawole AE, Olusegun $A O$ and IA Ayodele, 2011. Fundamentals of fish farming in Nigeria. Published and printed by Walecrown ventures Ibadan, Nigeria. Pp. 40-42.

12. Mamman T, Ipinjolu JK and I Magawata, 2013. Haematological indices of Clarias gariepinus (Burchell, 1882) fingerling fed diet containing graded level of Calabash (Lagenaria vulgaris) seed meal. Journal of Biology, Agriculture and Healthcare, 3: 100-104.

13. Mishra P and S Gupta, 2014. Haematological evaluation of Eclipta alba root extract in Catfish, Clarias bratrachus (Linnaeus, 1758). Journal of Pharmaceutical and Scientific Innovation, 3: 239-244.

14. Monein-Abdel A, Shabana, Khadre EM and $\mathrm{HH}$ Abdel-Kader, 2008. Physiological and histopathological effects in catfish exposed to dyestuff and chemical wastewater. International Journal of Zoology Research, 4: 189-202.

15. Ochang SN, Oyedapo F and TA Olabode, 2007. Growth performance, body composition, haematology and product quality of the African Catfish (Clarias gariepinus) fed diets with palm oil. Pakistan Journal of Nutrition, 6: 452-459.

16. Odeyemo OK, Adedeji OB and CC Offor, 2010. Blood lead level as biomarker of environmental lead pollution in feral and cultured African catfish (Clariasgariepinus), Nigerian Veterinary Journal, 31: 139-147.

17. Okomoda VT, Ataguba GA and VO Ayuba, 2013, Haematological response of Clarias gariepinus fingerlings exposed to acute concentration of Sunate. Journal of Stress Physiologyand Biochemistry, 9: 271-278.

18. Olufayo $M$ and AOlufunke, 2012. Haematology and gill pathology of Heterobranchus bidorsalis exposed to sublethal concentration of Moringaoleifera leaf extract, Journal of Agriculture and Biodiversity Research, 1: 18-24.

19. Olurin KB, Olojo EA, Mbaka GO and AT Akindele, 2006. Histopathological responses of the gill and liver tissues of Clarias gariepinus fingerlings to the herbicide glyphosate. African Journal of Biotechnology, 5: 2480-2487.

20. Poleksic $\vee$ and $\vee$ Mitrovic-Tutundzie, 1994. Fish gills as a monitor of sublethal and chronic effects of pollution In: Mulls, R, Llyod (Eds) on freshwater fish. Fishing News Books, Oxford. London. Pp339352.

21. Selvaraj D, Leena $R$ and $C$ Kamal, 2015. Toxicological and histopathological impacts of textile dyeing industry effluent on a selected teleost fish Poecilia reticulate. Asian Journal of Pharmacology and Toxicology, 3: 26-30. 